\title{
"I have such sad news": Loss in Finnish North American Letters ${ }^{1}$
}

\author{
Samira Saramo
}

University of Turku

\section{ABSTRACT IN ENGLISH}

Life writing has been an important tool for people to work through loss in their lives. In the context of twentieth-century migration, word of death and shared mourning occurred primarily through letters in the international post. Focusing on letters written by Finnish immigrants in the United States and Canada from the 1940s-1960s, this article analyzes some of the ways that letter writing has been used to address death and loss. Positioning personal letters within the broader field of life writing, this work examines how both loss and life writing often trigger a re/defining of the self, addressed in multiple and ambiguous ways by individual mourner/writers. In its unsettling of life, feelings, and connections, loss is a rupture of the self. By narrating their life, writers create personal chronologies, position themselves in places and communities, and declare their values. The life writing of Finnish North Americans provides windows into the difficult work of trying to assign meaning to meaning-defying loss.

\section{ABSTRAKTI SUOMEKSI}

Omaelämäkerrallinen kirjoittaminen on ollut tärkeä väline menetysten työstämisessä. 1900-luvulla siirtolaiset tiedottivat kuolemasta ja käsittelivät yhteistä surua ennen kaikkea kaukopostina kulkevien kirjeiden välityksellä. Tässä artikkelissa tarkastelen Yhdysvalloissa ja Kanadassa asuneiden suomalaisten siirtolaisten 1940-1960-luvulla kirjoittamia ja vastaanottamia kirjeitä kuoleman ja menetysten näkökulmasta. Asemoin kirjeet laajaan omaelämäkerrallisen kirjoittamisen kenttään pohtien menetysten ja elämäkerrallisen kirjoittamisen 
synnyttämää tarvetta minuuden uudelleen määrittelyyn, mikä ilmenee surevien kirjoituksissa monin erilaisin ja monimutkaisin tavoin. Elämän jatkuvuutta, tunteita ja ihmisen välisiä yhteyksiä järkyttävänä tapahtumana läheisen ihmisen menetys merkitsee myös minän ja minuuden katkeamia. Kertomalla elämästään kirjoittajat luovat henkilökohtaisia kronologioita asemoiden itsensä paikkoihin ja yhteisöihin ja määrittelevät arvojaan. Pohjois-Amerikan suomalaisten omaelämäkerralliset kirjoitukset avaavat ikkunoita menetysten käsittelyyn ja merkityksellistämiseen.

Keywords: Letters; Death; Loss; Finnish North Americans

On March 20, 1963, Hilja sent a letter from Florida to her sister Maria in Finland. It opened: "Dear Relatives, I don't really know how to begin. I will first say thanks for your letter. I have such sad news to now say as my husband Frans died on February 12th." ${ }^{2}$ Hilja's letter, which detailed her husband's death and her own grief, is part of the long tradition and necessity of sharing loss through the international post. Focusing on letters written by Finnish immigrants in the United States and Canada from the 1940s-1960s, this article analyzes some of the ways that letter writing has been used to address death and loss. Positioning personal letters within the broader field of life writing, this work examines how both loss and life writing often trigger a re/defining of the self, addressed in multiple and ambiguous ways by individual mourner/ writers.

The focus of the studied letters is on death, but the concept of loss provides a more encompassing and more fruitful lens for analyzing the experiences and emotions of the letter writers. Migration has long been associated with loss. For example, academically, this link was emphasized in Oscar Handlin's The Uprooted, which characterized the experience of migration as an experience of loss. ${ }^{3}$ While Handlin's work has been challenged and built upon over the years, migrants' own narratives continue to emphasize the loss(es) that accompany migration. Furthermore, letter writing has long been problematized through its relationship with loss. In The Postcard, Jacques Derrida posited that loss is the impetus of epistolarity. ${ }^{4}$ More recently, scholarly focus has been on the active relationships at the core of correspondence, demonstrating the work of "letters [as] the continuation of presence." ${ }^{5}$ Yet, such a need to recreate presence inherently rises from the loss of face-to-face contact. When letters deal specifically with death, such as those studied here, the interplay of loss and letter writing becomes further complicated. Definitions of loss capture the concept's ambiguous roles as fact, 
process, and feeling, and tie it to people, places, and things. ${ }^{6}$ Death for the bereaved is the loss of a person and of a relationship, but letters reveal the multiple losses that are experienced and narrated when the life of someone dear ends.

The letters used in this study are from the rich but underutilized Satakunta Letter Collection at the University of Turku, in Finland. The archive of some 10000 letters was collected in the early 1960s by researchers, who visited the towns and villages of the Satakunta province, appealing for donations of letters written by relatives and friends who had migrated to the United States and Canada. The collected letters are accompanied by short questionnaires about the migrant, and donors provided information to varying degrees. In some cases, the questionnaires inform us of the migrant's family and work background, relationship to the donor, when they departed from their home village and where they went. Based on a review of a dozen Satakunta villages, the present study analyzes the letter collections of thirty-five letter writers, chosen for the presence of loss in their correspondence. While the letters are from an open access archive, full names and detailed locations have not been used. Given the sensitive and highly personal nature of the letter content, their relatively recent composition, and since only the letter recipient donors formally consented to their participation in the collection, anonymizing personal details aims to provide the life writers with a safe space for their loss. Quoted passages have been translated by the author. The translations are intentionally unpolished and often literal, in an effort to bring the life writer's voice, Finnish North American cultural background, and literacy to the fore.

\section{LIFE WRITING}

The term life writing encompasses the genre and multiple forms of personal writing. Marlene Kadar defines life writing, in part, as "texts that are written by an author who does not continuously write about someone else, and who also does not pretend to be absent from the text." Delineating the field in the early 1990s, Kadar signaled the problematics of "the less 'objective' or more 'personal' genres such as letters and diaries" that seem to still challenge scholars, decades later. ${ }^{8}$ Memoirs and autobiography have easily fallen under the umbrella of life writing studies, but personal letters-particularly, I would argue, the letters of 'ordinary' people-are still undergoing integration within the field. If autobiographical narratives, such as life writing, insist on the presence of the author and focus on the self, how can a letter be distinguished as 
any more subjective or personal? I am interested in pursuing the "leaky" edges and intersections of letters and life writing, as Margaretta Jolly and Liz Stanley have encouraged. ${ }^{9}$

Concerns are readily voiced about the challenges of letter analysis. Most commonly, scholars have only one side of a correspondence, raising questions about the nature of the epistolary exchange and how the studied letters may be interacting with news and queries coming from the other side. There is a discomfort in the uncertainty of what a particular corpus of letters may represent in the full scope of the correspondence. At times it is impossible to tell if letters have disappeared or been destroyed, and whether such explanations may account for gaps between letters. Others discount the narrative value in the personal letters of 'ordinary' people, pointing to their often formulaic composition. Yet, such criticisms could be extended to many life writing forms, particularly the 'non-literary' immigrant autobiographies popular in North American ethnic communities. ${ }^{10}$ Such works often demonstrate an adherence to chronological narrative and clichéd formulations that suit the writers' conceptions of what such texts should be like.

The most obviously significant difference between letters and other autobiographical texts is that letters are personal relationships at work across a distance and that they have an exchange at their core. The letters of 'ordinary' writers, as Stanley reminds us, are a part of everyday practices, in both migrant and more localized forms ${ }^{11}$ Letter writing served a countless number of social, cultural, and individual needs for immigrants and created tangible links between friends and family separated by physical distance. This active process of relationship maintenance, however, often relied on autographical narratives much akin to those found in autobiography/memoir. Alistair Thomson has noted that correspondences relying on slow or irregular postal services (and I would add slow or irregular letter exchange) commonly adopt more traditionally autobiographical forms. ${ }^{12}$

More than differences and unique challenges posed by their form, the study of personal letters reveals much in common with other autobiographical texts. Thomson's summary of letter writing demonstrates these connections well: "Letter-writing involves a creative tension between careful concealment and descriptive detail, between the priority of the relationship or the record, between writing for self and writing for others." ${ }^{13}$ Audience, purpose, and timing are crucial analytical considerations for all life writing. In life writing, letters included, we witness the writers' fluidity of identity, time, and place. Personal letters as life writing reveal complicated selves and writers working through and representing who they are in varied and changing ways. 


\section{LOSS THROUGH LIFE WRITING}

Laura Ishiguro has poignantly noted that "the condolence letter was both insufficient and indispensable for expressing grief and consolation at a distance." ${ }^{4}$ This tangled duality is very present in the letters of Finnish immigrants in Canada and the United States. The letter was indispensable in practical terms at times when telephone or telegram communication was unavailable, too costly, or too awkward for meaningful expressions of grief. For some, writing served as an indispensable tool for making sense of loss. In Tuija Saresma's self-reflexive exploration, "Art as a Way to Life': Bereavement and the Healing Power of Arts and Writing," writing became a way of reorganizing life and a "way of life." ${ }^{5}$ Maarit Leskelä-Kärki has shown how anxiety and loss fueled the life writing of Aino Kallas, serving as a way of "banishing" sorrows. ${ }^{16}$ For Finnish North Americans, both writing and reading letters were significant at times of loss. While writing about loss could be therapeutic, receiving letters after the death of someone close could also be very important. Nikolai wrote two times in one letter following the death of his wife about how getting a letter could ease his pain. "Write some word," he encouraged, "even a letter can console in sorrow." "17

However, words can also fall short of expressing and making meaning out of loss. Writer Joan Didion noted that the death of her husband was "a case in which I need more than words to make meaning." ${ }^{18}$ Life writing rarely succeeds in a tidy "coming to terms" with death. Instead, such writing may better demonstrate the active and difficult processes of "working through" or "making sense." ${ }^{19}$ The Finnish North American letters most often show the ambiguous "textured recovery" that commonly accompanies life writing practice, as analyzed by Amy-Katerini Prodromou in Navigating Loss in Women's Contemporary Memoir. ${ }^{20}$ Letter writing and reading could provide a sense of order and connection, and an outlet for grief and memory, but it could also be disorderly, disturbing, and disheartening. The sad duty of informing kin about a death and putting thoughts and experiences to paper could be very painful. Sending word five weeks after her husband's death, Hilja could only bring herself to write to one sister. She explained: "These sorrowful things are so sad/unpleasant to write about so I will write this just to you and be so good as to tell Eeva's family and other relatives what grief I have been met with. I would write to you all separately but it's so sad to write." ${ }^{21}$ Loss defies easy expression and enunciation. Hilja wrote about not knowing how to begin to share her sorrowful news. She fell back on the convention of beginning a letter by giving thanks for a letter received, giving her writing structure amid the chaos of loss. 
Letters at times of death are insufficient because loss represents a multifaceted rupture. Death is a sudden change in daily life, breaking routines and demanding new tasks. Helmi expressed her grief by writing "now I'm so sad I don't seem to know how to do anything." ${ }^{22}$ Helmi's words speak to dizzy emotions and new daily realities. Loss is an emotional rupture, which plays out in countless variations and cannot be easily generalized. Beyond the deceased being taken away from their community, loss can also be a rupture of other relationships. In Ishiguro's words: "Death challenged the boundaries of family, changed its relationships, and provided disconcerting reminders of disconnection and distances of all kinds." ${ }^{23}$ In its unsettling of life, feelings, and connections, loss is a rupture of the self. Such a rupture often places a person in the position to re/define their self and life writing provides windows into these difficult negotiations. Life writing can be framed as a project of personal continuity. By narrating their life, a writer creates a personal chronology, positions themselves in places and communities, and declares their values, all of which contribute to identity. In the face of rupture, however, one's personal continuity may take nonlinear paths and ideas about 'progression' rarely apply.

\section{RE/DEFINING SELVES}

Constructions of time, 'truth', and the 'I' in life writing demonstrate the varying approaches people use to narrate loss in their lives. Time is a central element in the letters of Finnish immigrants in Canada and the United States. In these letters, as in migration life writing more broadly, there is a clear sense of time before migration and time after. Bridging these two periods of life, the memories or events that come to represent the moment(s) of departure are returned to frequently in life writing narratives. Likewise, in narratives of mourning, there is time before death and time after. In both narratives of migration and death, we may see how loss rewrites personal timelines and time begins to be counted in new ways. For example, Hilja's archived collection of letters to her sister spans several years. The death of her husband occurs about half way through the available correspondence. After his death, grief is a major presence in the letters and the passing of time is always noted in relation to the death (six months has passed, a year has passed, two years...). ${ }^{24}$ Joan Didion's The Year of Magical Thinking echoes Hilja's letters, overflowing with demarcations of time-even down to hours-that separate life before her husband's death and after. ${ }^{25}$ Didion makes clear how the temporal "divide" is "black and white." ${ }^{26}$ However, the processes of articulating personal chronologies are rarely tidy and linear. In Didion's narration of her first 
year of grieving/mourning, all kinds of pasts interlaced with her difficult new present. As Smith and Watson have noted about life writing generally, "time-now and time-past can interpenetrate in ways that confuse the relationship of one time to another." ${ }^{27}$ Such conflating and confusing of memories and time-both intentional and unintentional-can serve the purpose of structuring peoples' life narratives.

By reading life writing in a way that lets go-even if only momentarilyof concerns about "objective" capital-T-Truth, accuracies, and inaccuracies, we may witness personal processes of collecting and building selves and histories. If we accept the contention that life writers are always telling a truth about themselves (as they see it, wish to see it, or wish others to see it), we can begin to unpack the complexities of truth-making. As Natalie Zemon Davis observes, "shaping choices of language, detail, and order are needed to present an account that seems to both writer and reader true, real, meaningful, and/or explanatory." ${ }^{28}$ David Gerber has framed this as "narrative truth, which assists in establishing continuity and stability amidst the inconsistencies and the frequent contradictions of life," arguing that it "is more important for individuals than literal truth when it comes to the ongoing work of constructing personal identities." ${ }^{29}$ Formulations of such narrative truth are woven amongst constructions of emotional truths. ${ }^{30}$

In narrations of loss, life writers (like other mourners) commonly seek to justify or rationalize the death of a loved one. In the search for truth, old age and long-term illness may offer some sense to meaningdefying death. Likewise, clinging to the comfort of knowing that the deceased did not have to suffer long may ease (even if fleetingly) the troubled mind. The death of children and young people, on the other hand, particularly challenge mourners' abilities to make sense of death and to fit loss into cohesive life narratives. "We have had sorrow upon sorrow...," wrote one letter writer about the recent deaths of both her mother and granddaughter. ${ }^{31}$ She explained: "Yes, it was sad-sad it was when Mother died but—she was ill and already old—but—-the girl was only 16 years [.] She was to all of us so beloved, so good and God believing. But now she is gone and will never come back." ${ }^{32}$ Mourners try to make sense of the timing of death. Elsa wrote about the accidental death of her young nephew, struggling with the truth of time: "Oh if only he our beloved had some deterrent so he wouldn't have gone out on the ice. Now only to say again that you can't get ahead of death." ${ }^{33}$ In their own unique ways of "magical thinking," desperate for the return of their lost loved one, the writers search for ways they could have done more or been more. Mourning the death of her brother in Finland, Laura wrote from California: 
Now again our band has gotten smaller and it always comes as a surprise and we always each one revolt [wondering] why did our loved brother have to be taken from us. I was hoping that I'd still see him but that wasn't allowed for me... Why didn't I write some line to my brother now and again? But who among us has been so good that they couldn't have done and acted better. ${ }^{34}$

The letters of loss written by the studied Finnish North Americans show varied forms of dynamic and intersectional narrated-Is. In narratives of loss, it is common to see breaks in uses of first-person $I$ as such difficult emotions can require distancing from the present self. ${ }^{35}$ Take for example the way Fanni wrote about the death of her friend and longtime correspondent: "Yes, it is sorrowful there for you all now that she went away. Yes, many remember her fondly because she was so friendly and understanding-all the best qualities." ${ }^{36}$ Fanni may have spoken to her own feelings but she chose to frame these characterizations without narratively evoking herself. In addition to sheltering one's self, moving away from the I could also make space for the community of mourning and (ultimately, even if never fully) healing. In Sirpa's story, Saresma sees the shift in use of $I$ to "we" as a sign of the importance of family in the coping process. ${ }^{37}$ Cynthia Huff has questioned the "auto" of "autobiography," seeing the workings of community(ies) so strongly contained within these texts that claim to be about the self. ${ }^{38}$ The narrated and narrating $I \mathrm{~s}^{39}$ are built out of their community identifications, and such negotiations are quite close to the surface at times of loss.

One's sense of place and belonging are challenged by death. As Prodromou notes, "the whole concept of self must be reworked and revisited when we attempt to define ourselves within the literal (geographical) and psychically altered space that results from this new absence." 40 The death of a loved one calls to question meanings and markers of home. Is your house still your home when your spouse has passed away? The letters show several Finnish North American life writers, particularly seniors, working through such questions. Is the town you live in still meaningful after the death of someone close to you, especially if they were the primary breadwinner? In her published autobiography, Under the Northern Lights, Finnish Canadian Nelma Sillanpää wrote about the death of her father: "I was only thirteen and overcome with grief. Now there were only Mother and myself with no relatives in Canada. Mother tried to keep the restaurant going, but it was a hard life. We stayed [in Cochrane] until school was over in June, and then we moved to Timmins." ${ }^{41}$ Without her father, Cochrane lost its significance and economic viability for the family. Karen Wilson Baptist, writing about the death of her parents, reflected on the feeling 
of being "unfettered and groundless, for the landscape of home and of family seemed now lost to me forever." ${ }^{42}$

Place serves as an especially poignant marker of self in the letters of migrants. The moment of departure and the lines between the here and there of migration become deeply engraved. Carl's November 1949 letter from Minnesota, to sister Aksa demonstrates such melancholic, nostalgic remembrances: "I remember especially well when mother, Aksa, and Anne stayed there when I left there to start the journey to this promised land where I have lived to the evening of my life." ${ }^{\text {"33 }}$ Eerika Koskinen-Koivisto and Hanna Snellman have found that "nostalgia is often attached to topics and periods of time that are linked to a certain amount of struggle and misery, and above all contradictions." ${ }^{.44}$ When the deceased and bereaved are separated by borders and geography, belonging and mourning are hard to pin down. Loss and life writing have the power to transport the mourner/writer. After receiving word of the death of her sister's son, Elsa wrote: "I've been the whole day with you in my thoughts." ${ }^{\text {"5 }}$ Such psychic travels could both bring solace and make distances glaringly clear. Ishiguro notes how for migrants, with passing time and deaths, "the 'home' of their imagination and memory shifted and disappeared in their absence. ${ }^{\$ 46}$ This realization of change could be a heavy loss in and of itself.

\section{THE RELATIONSHIPS IN LETTERS OF LOSS}

The practice of life writing presents writers with the opportunity and challenge to work through their connections and relationships, resulting in what Christopher Craft referred to as a "binding and unbinding." ${ }^{27}$ In the exchange that characterizes letter writing, Ishiguro argues that "condolence letters enabled relatives to assert claims to family and relationship by iterating shared connections to the dead, and with each other." ${ }^{18}$ The letters of Finnish immigrants in North America, as with the British colonial family of letter writers studied by Ishiguro, demonstrate that when someone had been away from the home community for a long time, there could be a feeling of exclusion from deep mourning. This was particularly pronounced in cases where regular correspondence had not been established and when a migrant had not been present to care for and say farewell to the dying. ${ }^{49}$ Pat Jalland's study of death in Victorian England found a social expectation that family members and close friends be made aware of the details of a person's death. ${ }^{50}$ Finnish North American letters into the 1960s suggest that such an expectation was also present. Kaarlo's 1958 letter, for example, explains that he had heard about the 
death of a relative but was still waiting for someone to fill him in on the details of the passing and funeral arrangements. ${ }^{51}$ Waiting for word and feeling distanced in mourning could serve to emphasize loss of place, connection, and time.

Death could also forge new connections. At times, the death of a letter writer was announced to their correspondent by the deceased's spouse or other intimate, and, then, the correspondence began to take on a new form-a new life. On August 23, 1959, Frank wrote to sister-in-law Lyydia: "I've never written to you before. Sanni has always written but now she will not be writing anymore. I am just letting you know that Sanni died July 25 th and was buried on the 29th." 52 This announcement was followed by an attempt to establish a connection and concludes by encouraging letter exchange.

For some, death triggered reconnection after long silences. Sven wrote in September 1937: "Dear Mother and Brother, If you are still alive I will pen some lines. I received news that you are longing for me. I have gotten notice from there that Father has died there and that you would like to know something of me." ${ }^{53}$ The letter opening established a clear separation between "there" in the home village in Finland and Sven's distant new life. The death of his father generated an irregular letter exchange. The five archived letters, spaced over a decade between September 1937 and August $1947,{ }^{54}$ suggest a man bound by blood but less so by affective ties. The collection serves as a useful reminder of the numerous types of connections people have, including those that do not uphold romantic notions of familial intimacy. Religion seemed to drive a wedge between him and his brother, and prevented deeper engagement. The building tension between atheist Sven and his Christian brother is exemplified by the final available letter. Sven wrote:

\footnotetext{
Dear Brother, Now I draw near to you with a few lines after a long time and thank you for the letter which I have received in which you said that Mother has died there, already gotten to her eternal rest. Yes, it's best for Mother since she has already for so many years had to be in bed. That's where every last one of us is going in one way or another. No niin. ${ }^{55}$ Yes, I have gotten all of your letters but I have not replied for the reason that in every letter there is that religion and full of Bible verses and because I don't believe anything like that. Now I have to say to you, brother, that if you write to me, keep that God and hell out of the letters... ${ }^{56}$
}

Even at a time of death, Sven did not find comfort in the Lutheran teachings he had likely been raised on. Neither did he give space for his brother to take solace from his religious beliefs, demonstrating two very different responses to loss and the distance between them. 


\section{REFLEGTIONS ON MORTALITY}

Sven responded to the loss of his mother by acknowledging the end of her suffering ("it's best for Mother since she has already for so many years had to be in bed") and the inevitability of death ("That's where every last one of us is going in one way or another."). Sanni similarly tried to comfort her sister by emphasizing the certainty of death, writing: "[You] shouldn't too much think or grieve because this is nature's law that orders this for us all. ${ }^{57}$ Death very often prompted Finnish North American letter writers to reflect on their own mortality. Lines like "maybe we will still see each other if living days are left" hinted at the writer's heightened sense of the fleetingness of life, prompted by the loss of a family member or friend. ${ }^{58}$ For many, leaning on religious belief offered comfort in the face of mortality. Following his wife's death, Nikolai wrote: "now, then, I am totally alone like an orphan boy[,] relatives and acquaintances are all so far away. It's only a bad thing if something should happen I may be even weeks dead before anyone knows anything, but the Lord protects everyone as best as he can." 59

Death could also inspire fuller expression of contemplations on life. Such an example is offered by Hilma's December 4, 1960, letter. Hilma, who had previously lost her spouse, wrote her condolences to her sister upon the death of her husband. After acknowledging the sorrow caused by the loss of a spouse, she began to reflect on the end of life:

\footnotetext{
When a person is young then there is a very large desire to live. You love work and with each day you hope for new and better. But when your time you've spent with work you start to see that this life isn't too special after all. Old age comes, you find your interest in life and people is at their end and you're like a ripe fruit that's ready to detach from the tree and fall on the ground. And how good it is after all that the Lord has put a place where he moves us people when we've became needless in this life. ${ }^{60}$
}

If the thought of her deceased husband's un-special life, left rotting on the ground like spoiled fruit, did not comfort the newly widowed, Hilma encouraged her sister: "Trust in the Lord your sorrows for he will take care of you." ${ }^{\prime 61}$

\section{THE PRESENCE OF DEATH}

Hilma insightfully imparted, "yes, death is such a sad/unpleasant visitor in a home." ${ }^{\prime 2}$ Though death represents a loss, it insists on presence. Well into the twentieth century, death marked its presence in Finnish and 
Finnish North American homes through rituals such as covered windows and mirrors, wreaths on doors, and the laying out of the corpse in the home. ${ }^{63}$ It inscribes itself on the bodies of mourners, historically in the mourning clothes of women, and through physical aches and the weight of being pulled down in sorrow. ${ }^{64}$ Letters demonstrate that when mourners were separated by geographical distances, loss, regardless, insisted upon a material presence. Among the studied letters, when life writers acknowledged having received word of a death in Finland, they, almost without exception, expressed their desire to extend a material gesture. Most commonly, this meant enclosing a few dollars so flowers could be purchased for the grave, like Lempi did in $1957 .{ }^{65}$ When his father died, Semmi wanted to bridge the distance between the United States and Finland, writing: "Don't you yet put on Father's grave any kind of cross. When I come there to home I will then put a stone on Father's grave or will send money for it even before that." ${ }^{" 6}$ The gravestone stood as a material signifier of Semmi's home and grief. When someone died in North America, it was common to send obituary clippings or photographs from the funeral (an important Finnish death custom). In August 1959, Frank included a photo and wrote, "I'm putting here with the letter one of these funeral pictures as a memory of Sanni." ${ }^{\prime 7}$

While the letters analyzed here did not bring to the surface any such examples, black-edged mourning stationary commonly announced Finnish deaths before the envelope was even opened. ${ }^{68}$ With or without this telling marker, the letters themselves served as significant material markers of death's presence, sometimes taking on a life of their own that long outlasted the immediate, acute period of loss and mourning. Though leading us into speculative territory and possibly academic discomfort, in the archive we may find traces of people's intimate relationships with letter writing and loss. Working with the Satakunta letter collection, I noted that single letter donations commonly told of someone's death or extended sympathy, suggesting the importance assigned to physical letters confronting loss. These expressions, solidified on paper, were deemed worthy to save and, furthermore, to donate for historical preservation. The case of single letter donations, of course, raises questions about the potential scope of a correspondence, whether the existing letter was the only one that had been saved and, if not, why that particular letter had been entrusted to the archive.

The Satakunta letter collection is organized by village, which allows researchers to easily identify letters written by the same person to several people in the home community, as well as letters written to the same person by several emigrants. A moving example are the three donations made by Aina: three large, brown manila envelopes, each containing one 
letter. One letter had been written by sister Elsa and another by sister Maiju. Both were written in April 1953, when the sisters in the United States had learned that Aina's young son Kalle had fallen through the ice and drowned-his body was still missing. The letters share in the grief of Aina's family and try to make sense of the senseless tragedy. Both letters also suggest active connections among the sisters. There is a sense that regular correspondence between the three was maintained. Yet, only these two letters were saved or at least donated. Opening the third envelope, I assumed I might find another condolence letter. The third letter, however, was written by Aina's sister-in-law Tekla in Quebec in 1960. Unlike the letters from Elsa and Maiju, this letter suggests an irregular connection, a catching up after passed time. The letter had a very different tone than that of the other two donations. On the third page, however, Tekla wrote: "Yes things went sadly/badly for you when your son drowned. Indeed, I would probably die if our son drowned." ${ }^{69}$ While speculative, could it be that this acknowledgment of grief and reminder of a son gone seven years made this letter worthy of being tucked away with the other two precious condolence letters? In the context of regular letter correspondence, Liz Stanley has written about "the letter providing metonymic traces of the absent person." ${ }^{\prime 0}$ In the case of loss, letters hold space for the beloved deceased, collectively created through the correspondents' expressions of grief and condolence.

\section{CONCLUSION}

On January 19, 1953, Maria wrote:

I received a telegram on the 16 th that my beloved brother has moved to from where there is no returning. It was a big hit for us all but most of all for you and your children... I had known that he had been sick but I didn't believe it to be this serious. Elvi had even written that Father was better. I don't understand why it's touching/affecting me so hard/deeply that nothing becomes of anything except for weeping. Dear Hilma, don't take this so hard now that you would go right after him, stay and be security for Pentti boy. ... Put a little wreath from me too for my brother's memory... Now take some photos from all the parts of the funeral so that I can get some too. Then when you are able to, write to me about his illness and death. ...you have funeral tasks and they are not fun tasks. It is so sad to not be able to be with you... ${ }^{71}$

Maria's letter captures all of the key components at the core of Finnish North American life writing on loss. Emotion is close to the surface and the writer shows an attempt to make sense of the significant rupture 
caused by the death of her brother, grasping for an understanding of the timing and the reasons or "truths" (her brother's illness) for why it had to be so. With geographic distance between them, she struggled to understand the illness and asked to be told more. Maria drew on her connections and community of grief, largely deferring her own emotional experience for the feelings of her sister-in-law and their children. The realization of mortality is present and the possibility of another death (Hilma's) had come to mind. Maria desired to honour the presence of this loss by offering a wreath and by asking for funeral photographs in return. Even these cannot overcome the pain of distance.

Life writing provides an opportunity to learn about death in postwar Finnish North American communities and how the immigrants who set their thoughts and feelings to paper expressed and represented loss and mourning. For life writers, loss allows an opportunity to rely on familiar formulas for narrating, such as the condolence letter and the dignified commemorative passage in an autobiography. These are used (mostly subconsciously) as a way to participate in cultures and communities the writer identifies with - a narrative subscription to death ritual.

The comfortable familiarity of these narrative conventions also provides a way to break into very personal and individual feelings, responses, and circumstances surrounding loss. Loss and life writing provide opportunities to re/define one's sense of self, place, and order. On one hand, loss prompts narration but, on the other, it rarely lends itself to easy words. Faced with death from a distance, Finnish North Americans turned to personal letter writing to make meaning out of the incomprehensible.

\section{WORKS CITED}

\section{Archival Sources}

University of Turku Archives, Satakunta Letter Collection.

\section{Published Sources}

Armstrong, Karen. Remembering Karelia: A Family's Story of Displacement during and after the Finnish Wars. New York: Berghahn Books, 2004.

Craft, Christopher. Another Kind of Love: Male Homosexual Desire in English Discourse, 1850 1920. Berkeley: University of California Press, 1994.

Davis, Natalie Zemon. Fiction in the Archives: Pardon Tales and Their Tellers in Sixteenth-Century France. Stanford: Stanford University Press, 1987.

Derrida, Jacques. The Postcard: From Socrates to Freud and Beyond. Translated by Alan Bass. Chicago: University of Chicago Press, 1987.

Didion, Joan. The Year of Magical Thinking. New York: Alfred A. Knoff, 2005. 
Eronen, Veli. Kanadan kutsu [Canada's Call]. Turku: Migration Institute of Finland, 2001.

Gerber, David A. Authors of Their Lives: The Personal Correspondence of British Immigrants to North America in the Nineteenth Century. New York: New York University Press, 2006.

Gerber, David A. "Epistolary Masquerades: Acts of Deceiving and Withholding in Immigrant Letters." Eds. Bruce S. Elliott, David A. Gerber, and Suzanne M. Sinke. Letters Across Borders: The Epistolary Practices of International Migrants. Ottawa: Palgrave MacMillan, 2006. 141-157.

Handlin, Oscar. The Uprooted: The Epic Story of the Great Migrations that Made the American People. Philadelphia: University of Pennsylvania Press, 2002 [1951].

Huff, Cynthia. "Towards a Geography of Women's Life Writing: An Introductory Essay." Ed. Cynthia Huff. Towards a Geography of Women's Life Writing. New York: Routledge, 2005. $1-15$.

Ishiguro, Laura. "Relative Distances: Family and Empire between Britain, British Columbia and India, 1858-1901." PhD Dissertation, University College London, 2011.

Ishiguro, Laura. "'How I wish I might be near': Distance and the Epistolary Family in Late-Nineteenth-Century Condolence Letters." Eds. Henry Yu, Adele Perry, and Karen Dubinsky. Within and Without the Nation: Canadian History as Transnational History. Toronto: University of Toronto Press, 2015. 212-227.

Jolly, Margaretta and Liz Stanley. "Letters as/not a Genre." Life Writing 2.2 (2005): 91-118.

Kadar, Marlene. "Coming to Terms: Life Writing - from genre to Critical Practice." Ed. Marlene Kadar. Essays on Life Writing: From Genre to Critical Practice. Kadar: Toronto: University of Toronto Press, 1992. 3-16.

Koskinen-Koivisto, Eerika and Hanna Snellman. "Bittersweet: Everyday Life and Nostalgia for the 1950s." Journal of Finnish Studies 19.2 (July 2016): 1-6.

La Capra, Dominick. Writing History, Writing Trauma. Baltimore: The John Hopkins University Press, 2001.

Larson, Thomas. The Memoir and the Memoirist: Reading and Writing Personal Narrative. Athens, OH: Swallow Press/Ohio University Press, 2007.

Leskelä-Kärki, Maarit. "Songs of Comfort and Lamentation: Autobiographical Connections in the Texts of Ageing Aino Kallas.” Eds. Leena Kurvet-Käosaar and Lea Rojola. Aino Kallas: Negotiations with Modernity. Helsinki: SKS, 2011. 201-217.

Oxford English Dictionary entry on "Loss." Available at http://www.oxfordreference.com/ view/10.1093/acref/9780199571123.001.0001/m_en_gb0482080?rskey=VekSPi\&result=1.

Pajari, Ilona. "Kuolemanrituaalit Suomessa" [Death Rituals in Finland]. Eds. Outi Hakola, Sari Kivistö, and Virpi Mäkinen. Kuoleman kulttuurit Suomessa. Helsinki: Gaudeamus, 2014. 87-106.

Prodromou, Amy-Katerini. Navigating Loss in Women's Contemporary Memoir. London: Palgrave Macmillan, 2015.

Saramo, Samira. "Life Moving Forward: Soviet Karelia in the Letters and Memoirs of Finnish North Americans." PhD Dissertation, York University, 2014.

Saresma, Tuija. "'Art as a Way to Life': Bereavement and the Healing Power of Arts and Writing." Qualitative Inquiry 9.4 (2003): 603-620.

Sillanpää, Nelma. Ed. Edward W. Laine. Under the North Lights: My Memories of Life in the Finnish Community of Northern Ontario. Ottawa: Canadian Museum of Civilization, 1994.

Smith, Sidonie and Julia Watson. Reading Autobiography: A Guide to Interpreting Life Narratives, Second ed. Minneapolis: University of Minnesota Press, 2010.

Stanley, Liz. "The Epistolary Gift, the Editorial Third-Party, Counter-Epistolaria: Rethinking the Epistolarium." Life Writing 8.2 (2011): 135-152.

Stanley, Liz. "Settler Colonialism and Migrant Letters: The Forbes Family and Letter-Writing in South Africa 1850-1922." The History of the Family 21.3 (2016): 398-428. 
Thomson, Alistair. "Life Stories and Historical Analysis." Eds. Simon Gunn and Lucy Faire. Research Methods for History. Edinburgh: Edinburgh University Press, 2011. 111-112.

Tiitinen, Gertrude. A Finnish American Family. Riverside, CA: Voitto Publishing, 1991.

Wilson Baptist, Karen. "Diaspora: Death without a landscape." Mortality 15.4 (November 2010): 294-307.

\section{ABOUT THE AUTHOR}

Samira Saramo is an Academy of Finland Postdoctoral Researcher at the University of Turku's John Morton Center for North American Studies (Finland). Saramo's multidisciplinary research focuses on ethnicity, gender, emotion, death, violence, place-making, and social movements in both historical and current contexts. Analyzing personal letters, memoirs, and social media narratives, Saramo is particularly interested in the form and accompanying challenges of life writing research. Her current research project, "Death and Mourning in Finnish North America," uses the case study of Finnish immigrants in 1880-1939 North America to explore the ways in which death and mourning produce ethnicity in everyday practices and personal narrations. Saramo holds a Ph.D. in History from York University (Canada).

\section{NOTES}

1 The author would like to acknowledge the support of the Jenny and Antti Wihuri Foundation and the Academy of Finland. Thanks also to the University of Turku's John Morton Center for North American Studies, Teutori Library, and to the colleagues and reviewers whose comments have strengthened the work.

2 Hilja letter, Florida, March 20, 1963. University of Turku Archives, Satakunta Collection, ALAS:III.

3 Oscar Handlin, The Uprooted: The Epic Story of the Great Migrations that Made the American People (Philadelphia: University of Pennsylvania Press, 2002 [1951]).

4 Jacques Derrida (trans. Alan Bass), The Postcard: From Socrates to Freud and Beyond (Chicago: University of Chicago Press, 1987).

5 Liz Stanley, "The Epistolary Gift, the Editorial Third-Party, Counter-Epistolaria: Rethinking the Epistolarium," Life Writing 8.2 (2011), 137. See also David Gerber, Authors of Their Lives: The Personal Correspondence of British Immigrants to North America in the Nineteenth Century (New York: New York University Press, 2006).

6 See for example Oxford English Dictionary entry on "Loss." Available at http://www. oxfordreference.com/view/10.1093/acref/9780199571123.001.0001/m_en_gb048208 0 ? rskey=VekSPi\&result $=1$.

7 Marlene Kadar, "Coming to Terms: Life Writing-from genre to Critical Practice," in Essays on Life Writing: From Genre to Critical Practice, ed. Marlene Kadar (Toronto: University of Toronto Press, 1992), 10.

8 Kadar, 4.

9 Margaretta Jolly and Liz Stanley, "Letters as/not a genre," Life Writing, 2.2 (2005), 100.

10 Two Finnish Canadian examples include Nelma Sillanpää, Under the North Lights: My Memories of Life in the Finnish Community of Northern Ontario, ed. Edward W. Laine (Ottawa: Canadian Museum of Civilization, 1994) and Veli Eronen, Kanadan kutsu [Canada's Call] (Turku: Migration Institute of Finland, 2001). 
11 See Liz Stanley, "Settler colonialism and migrant letters: the Forbes family and letterwriting in South Africa 1850-1922," The History of the Family 21.3 (2016): 398-428.

12 Alistair Thomson, "Life Stories and Historical Analysis" in Research Methods for History, eds. Simon Gunn and Lucy Faire (Edinburgh: Edinburgh University Press, 2011), 111-112.

13 Ibid., 105.

14 Laura Ishiguro, “How I wish I might be near': Distance and the Epistolary Family in Late-Nineteenth-Century Condolence Letters" in Within and Without the Nation: Canadian History as Transnational History, eds. H. Yu, A. Perry, and K. Dubinsky (Toronto: University of Toronto Press, 2015), 222.

15 Tuija Saresma, “'Art as a Way to Life': Bereavement and the Healing Power of Arts and Writing," Qualitative Inquiry 9.4 (2003), 604.

16 Maarit Leskelä-Kärki, "Songs of Comfort and Lamentation: Autobiographical Connections in the Texts of Ageing Aino Kallas" in Aino Kallas: Negotiations with Modernity, eds. L. Kurvet-Käosaar and L. Rojola (Helsinki: SKS, 2011), 210.

17 Nikolai letter, New Jersey, May 29, 1960. University of Turku Archives, Satakunta Collection, EURA:XVI.

18 Joan Didion, The Year of Magical Thinking (New York: Alfred A. Knoff, 2005), 8.

19 Dominick La Capra has fruitfully explored these concepts, along with "acting out," in Writing History, Writing Trauma (Baltimore: The John Hopkins University Press, 2001).

20 Amy-Katerini Prodromou, Navigating Loss in Women's Contemporary Memoir (London: Palgrave Macmillan, 2015).

21 Hilja letter, Florida, March 20, 1963.

22 Helmi letter, California, April 29, 1963. University of Turku Archives, Satakunta Collection, E-KI:VIII.

23 Laura Ishiguro, "Relative Distances: Family and Empire between Britain, British Columbia and India, 1858-1901" (PhD Dissertation, University College London, 2011), 180.

24 See also the ten letters of Martta written between 1956 and 1962. University of Turku Archives, Satakunta Collection, E-KI:XXVII.

25 Didion, for example, 71, 216-217, and 225.

26 Ibid., 148-149.

27 Sidonie Smith and Julia Watson, Reading Autobiography: A Guide to Interpreting Life Narratives, Second Edition (Minneapolis: University of Minnesota Press, 2010), 93.

28 Natalie Zemon Davis, Fiction in the Archives: Pardon Tales and Their Tellers in Sixteenth-Century France (Stanford: Stanford University Press, 1987), 3.

29 Gerber, David A. "Epistolary Masquerades: Acts of Deceiving and Withholding in Immigrant Letters" in Letters Across Borders: The Epistolary Practices of International Migrants, eds. B. Elliott, D. Gerber, and S. Sinke (Ottawa: Palgrave MacMillan, 2006), 147.

30 Karen Armstrong, Remembering Karelia: A Family's Story of Displacement during and after the Finnish Wars (New York: Berghahn Books, 2004), 112; Thomas Larson, The Memoir and the Memoirist: Reading and Writing Personal Narrative (Athens, OH: Swallow Press/Ohio University Press, 2007), 104.

31 Frank's daughter (name unknown) letter, December 9, circa 1950s (year unkown). University of Turku Archives, Satakunta Collection, EURA:XI.

32 Ibid.

33 Elsa letter, Connecticut, January 26 [?], 1953. University of Turku Archives, Satakunta Collection, E-KI:XXIII.

34 Laura letter, California, February 28, 1961. University of Turku Archives, Satakunta Collection, E-KI:VII.

35 Samira Saramo, "Life Moving Forward: Soviet Karelia in the Letters and Memoirs of Finnish North Americans" (PhD Dissertation, York University, 2014), 370-373. 
36 Fanni letter, Ontario, January 5, 1961. University of Turku Archives, Satakunta Collection, EURA:XXV.

37 Saresma, 611.

38 Cynthia Huff, "Towards a Geography of Women's Life Writing: An Introductory Essay” in Towards a Geography of Women's Life Writing, ed. C. Huff (New York: Routledge, 2005), 6.

39 For a useful overview of the various Is involved in the process of life writing, see Smith and Watson's Reading Autobiography.

40 Prodromou, 6.

41 Sillanpaa, 33.

42 Karen Wilson Baptist, "Diaspora: Death without a landscape," Mortality, 15.4 (November 2010), 294.

43 Carl letter, Minnesota, November 2, 1949. University of Turku Archives, Satakunta Collection, ALAS.

44 Eerika Koskinen-Koivisto and Hanna Snellman, "Bittersweet: Everyday Life and Nostalgia for the 1950s," Journal of Finnish Studies, 19.2 (July 2016), 5.

45 Elsa letter, Connecticut, January 26 [?], 1953.

46 Ishiguro, "Relative Distances," 204.

47 Christopher Craft, Another Kind of Love: Male Homosexual Desire in English Discourse, 1850 1920 (Berkeley: University of California Press, 1994), 60.

48 Ishiguro, "Relative Distances," 194.

49 Ishiguro, "How I wish I might be near," 219. Anna Matyska has examined the emotional and social challenges distance poses to transnational families at times of grief. See "Transnational Death Kin Work in Polish Transnational Families" (Unpublished essay, 2017).

50 Pat Jalland, Death in the Victorian Family (Oxford: Oxford University Press, 1996), 30.

51 Kaarlo letter, Massachusetts, January 26, 1958. University of Turku Teutori Archives, Satakunta Letter Collection, JÄM: LXIX.

52 Frank letter, Washington, August 23, 1959. University of Turku Archives, Satakunta Collection, EURA:XI.

53 Sven letter, Michigan, September 1937. University of Turku Archives, Satakunta Collection, JÄM:XCII.

54 Though it cannot be confirmed, it seems the time gaps between the archived letters may, in fact, be representative of the letter exchange. The letters refer to the passed time between letters and specifically to "last fall" etc.

55 A multifunctioning Finnish expression that in this case signals that the preceding topic has been exhausted.

56 Sven letter, Michigan. August 1947.

57 Sanni letter, Washington, August 23, 1959. University of Turku Archives, Satakunta Collection, EURA:XI.

58 Hilja letter, Florida, March 20, 1963.

59 Nikolai letter, New Jersey, May 29, 1960.

60 Hilma letter, Washington, December 4, 1960. University of Turku Archives, Satakunta Collection EURA:XIV.

61 Ibid.

62 Ibid.

63 See for example, Gertrude Tiitinen, A Finnish American Family (Riverside, CA: Voitto Publishing, 1991); Ilona Pajari, "Kuolemanrituaalit Suomessa" [Death Rituals in Finland] in Kuoleman kulttuurit Suomessa, eds. O. Hakola, S. Kivistö, and V. Mäkinen (Helsinki: Gaudeamus, 2014): 87-106.

64 For example the letters of Elizabeth, April 22, 1969 (ALAS); Nikolai, May 29, 1960; Helmi, April 29, 1963, among many others. Saresma also raises the contradicting weight and emptiness of sorrow. Saresma, 610. 
65 Lempi letter, Michigan, November 19, 1957. University of Turku Archives, Satakunta Collection, JÄM:LXVI.

66 Semmi letter, August 1910. University of Turku Archives, Satakunta Collection.

67 Frank letter, August 23, 1959.

68 Audience discussion at a Calgary Finlandia Cultural Association in July 2017, raised a lot of memories of mourning stationary from as recently as the late 1960s.

69 Tekla letter, Quebec, December 5, 1960. University of Turku Archives, Satakunta Collection, E-KI:XXIV.

70 Stanley, 136.

71 Maria letter, Minnesota, January 19, 1953. University of Turku Archives, Satakunta Collection, JÄM:VL. 